\title{
Short-term interactions between phytoplankton and intertidal seagrass vegetation in a coastal lagoon (Bassin d'Arcachon, SW France)
}

\author{
Rutger de Wit $^{\mathrm{a}, \mathrm{b},{ }^{*}, \text { Marc Troussellier }^{\mathrm{a}} \text {, Claude Courties }}{ }^{\mathrm{c}}$, Evelyne Buffan-Dubau ${ }^{\mathrm{b}, 1}$, Emmanuelle \\ Lemaire $^{b}$
}

\begin{abstract}
a "Ecologie des systèmes marins côtiers (Ecosym)". UMR 5119, Université Montpellier 2, CNRS, IRD, Ifremer, Université Montpellier 1, Place Eugène Bataillon, Case 093, 34095 Montpellier Cedex 05, France

b UMR 5805 "Environnements et Paléoenvironnements Océaniques et Côtiers", CNRS \& Université Bordeaux 1, 2, rue du Pr. Jolyet, 33120 Arcachon, France

${ }^{c}$ CNRS, UMS 2348, Observatoire Océanologique, Université Pierre et Marie Curie-Paris 6, 66651 Banyuls sur mer, France

1 Present address : EcoLab_Laboratoire Ecologie Fonctionnelle et Environnement-UMR 5245 (CNRS-UPSINPT), Université Paul Sabatier, Bât. 4R1, 31062 Toulouse cedex 9, France
\end{abstract}

*: Corresponding author : Rutger de Wit, email address : rutger.de-wit@univ-montp2.fr

\begin{abstract}
:
We experimentally simulated the temporality of the interactions between intertidal seagrasses and phytoplankton in the context of nutrient enrichment from continental origin. Phytoplankton development was retarded after 1-day exposure to intertidal Zostera noltii Hornemann vegetation samples, with respect to control treatments. This was not explained by resource competition and we hypothesized a direct interference between seagrass leaves and phytoplankton. After separation from the vegetation in 5-day incubations, the final yield of large phytoplankton, mainly diatoms and haptophytes, was determined by nutrient loading. In contrast, Synechococcus-like cells (SYN), phototrophic picoeukaryotes and nanophytoplankton decreased after day 3 , most likely due to grazing control. A second experiment was designed to test the pelagos-benthos coupling in more detail. Therefore, we compared the effect of aboveground biomass of $Z$. noltii alone with the effect of the entire vegetation including the sediment. This experiment did not provide unequivocal support for our initial hypothesis on direct interference competition between $Z$. noltii leaves and phytoplankton. Surprisingly, we found a spectacular decrease of SYN, phototrophic picoeukaryotes and nanophytoplankton in treatments with $Z$. noltii vegetation including the sediment, which could be attributed to benthic grazing by suspension feeders.
\end{abstract}

Keywords : Competition; Allelopathy ; Zostera noltii ; Sediment ; Intertidal vegetation ; Flow cytometry ; Photosynthetic pigments 


\section{Introduction}

A general conceptual framework for understanding the interactions between phytoplankton and seagrasses in shallow coastal lagoons and coastal bays has emerged from a synthetic analysis of the knowledge of ecological and biogeochemical processes occurring along nutrient enrichment gradients, where high nutrient conditions have resulted from humaninduced eutrophication (Schramm, 1999; Burkholder et al., 2007; McClathery et al., 2007; Viaroli et al., 2008). At low to moderate nutrient supply rates, the seagrasses are very competitive because of their specific nutrient economy (Schramm, 1999). These plants take up inorganic nitrogen and inorganic phosphorus through their leaves using high affinity uptake systems with half saturation constants $\left(\mathrm{K}_{\mathrm{m}}\right)$ ranging from 5-75 $\mu \mathrm{M}$ (Romero et al., 2006; De Wit et al., 2005). In addition, the nutrients are retained in the biomass of these plants and the $\mathrm{N}$ and $\mathrm{P}$ turnover times are long since the plants are relatively long-living and the mineralisation rates of their detritus are low. Thus, at low to moderate nutrient supply rates the plants function as an efficient filter for inorganic nutrients by storing the elements in their biomass and thus compete successfully with phytoplankton (McClathery et al., 2007; Viaroli et al., 2008). In contrast, phytoplanktonic communities do not allow storing large amounts of inorganic nutrients, since they exhibit a fast turnover rate due to grazing processes.

On the other extreme, i.e. at very high nutrient over-enrichment, the nutrient uptake capacity of the seagrasses is largely saturated and phytoplankton can competitively bloom using the nutrients dissolved in the water column. The blooming of the phytoplankton results in reduced light for the benthic vegetation and a positive feedback loop induces a self-accelerating process where seagrasses disappear leaving the stage to phytoplankton (Schramm, 1999; Burkholder et al., 2007; McClathery et al., 2007; Viaroli et al., 2008). In between these conditions, i.e. during the early phases of nutrient over-enrichment, the situation is more 
complicated as microalgae occurring as epiphytes on the seagrasses and floating macroalgae compete for nutrients both with the seagrasses (Valiela et al. 1997; De Wit et al., 2001; Viaroli et al., 2008) and the phytoplankton.

Nevertheless, this conceptual framework does not consider the impact of intertidal seagrass species. On the W-European and N-African Atlantic coasts, Zostera noltii Hornemann occurs widely distributed on intertidal mudflats (Green \& Short, 2003). Hence, the interactions between this seagrass species and phytoplankton are limited to high tides, while the pelagic communities are separated from the seagrass meadows at low tides. Hence, it is important to study whether the effects on phytoplankton will persist after separation of the pelagic community from these seagrasses and how long. These interactions may be based on competition between these two main types of primary producers. However, it should also take into account that the intertidal seagrass vegetation provides the habitat for a characteristic community comprising epibionts and benthic organisms, which also may interact with the water column.

In addition, while the general conceptual framework highlights the importance of competition for resources for the interaction between seagrasses and phytoplankton, direct interference competition as e.g. due to excretion of allelopathic substances has been poorly studied. Seagrasses produce secondary metabolites ((Todd et al., 1993; Jennsen et al., 1998) and it has been shown that methanolic extracts of $Z$. noltii have strong inhibitory impacts on the growth of a cultured phytoplankton species, i.e., the dinoflagellate Alexandrium catenella (Laabir et al., 2010). Recently, three phenolic compounds, i.e. rosmarinic, caffeic and zosteric acids have been identified and quantified in tissues of Z. noltii (Grignon-Dubois et al., 2011). In this study, we take the Bassin d'Arcachon as an example for studying the specific case of interaction between lagoonal phytoplankton and intertidal seagrasses. The Bassin d'Arcachon is a mesotidal lagoon of $156 \mathrm{~km}^{2}$ on the SW coast of France with very important 
ecological (Caumette et al., 1996; De Wit et al., 2001) and socio-economic values. It is home of the largest intertidal seagrass meadows in Western Europe built by Zostera noltii $\left(70 \mathrm{~km}^{2}\right)$ (Auby \& Labourg, 1996). Total nitrogen loading from the continent into the lagoon increased since the 1960 's and has stabilised the last ten years, it fluctuates between 60 to $120 \mathrm{~kg} \mathrm{~N} \mathrm{ha}^{-1}$ year $^{-1}$ according to climatic conditions (De Wit et al., 2005). The biogeochemistry of the $Z$. noltii system has been extensively studied and its susceptibility towards macroalgal blooming has been analysed (De Wit et al., 2001). In contrast, the interactions between nutrient cycling, phytoplankton and seagrass productivity have received little attention so far. It is anticipated that the interaction is particularly strong at water heights slightly above MWH when the tidal flats are submerged and water height above the sediment is small. During ebb tide, the water masses are withdrawn from the area where Z. noltii is present and the interactions with these seagrasses therefore stops temporarily or definitively depending on water flow patterns in the lagoon.

Our aim is to study the interactions between phytoplankton and intertidal seagrass in the Bassin d'Arcachon, as a specific case of the temporality of pelagos-benthic coupling. Therefore, we simulated the abovementioned temporal interaction short contact times between the seagrasses and the water mass and considered the impact of nutrient enrichment from continental origin on this interaction.

\section{Material and Methods}

\section{Sampling}

Z. noltii meadows were sampled at station A, which is located on the intertidal flats of Ile aux Oiseaux in the center of the Bassin d'Arcachon (Welsh et al. 1996; Bachelet et al., 
2000; De Wit et al., 2001) and water samples were taken from the major channel of the Bassin d'Arcachon in Rade d'Eyrac at Jetée Eyrac close to the Laboratory.

Sediment cores were sampled around low tide. Circular gray PVC cores with surface area of $0.0284 \mathrm{~m}^{2}$ and $10 \mathrm{~cm}$ depth were taken by gently inserting the cores into the sediment until the vegetated sediment surface was at the rim of the cores. Caution was taken not to damage the plants that occurred within the sampled areas and subsequently the cores were extruded. Core were transported to the lab in coolboxes (20 min. sailing time) and stored in large mesocosm tanks of 5001 seawater prior to use for experiments. The mesocosm tanks were located in a greenhouse under a glass roof allowing for $>60 \%$ of light transmission. The water column was continuously diluted with freshly sampled seawater at a dilution rate of 0.2 $\mathrm{h}^{-1}$, salinity was $35 \mathrm{PSU}$ and temperature maintained at $21 \pm 2{ }^{\circ} \mathrm{C}$.

\section{Experimental Procedures}

In a first experiment we simulated a nutrient-enriched water mass that was in contact with $Z$. noltii vegetation for a limited time (1 day) and followed phytoplankton development during the following 5 days. We found that phytoplankton development in this treatment was retarded with respect to both controls (see below), a phenomenon that could not be attributed alone to nutrient uptake by $Z$. noltii. Therefore, we designed a second experiment simulating short-term (1 day) interaction between the water mass and the Zostera noltii vegetation. We choose a factorial design including a control (no Zostera added), a treatment with leaves alone added to include resource and direct interference competition and a treatment including the intact plants rooted in the sediment. This allowed us to separate the effects of the above-ground Z. noltii biomass from the total effect of the vegetation including the sediment. The experimental procedure is depicted in Figure 2 and detail is described below. 


\section{Experiment 1}

Experiment 1 was performed early July 1997. The salinity of the water was 35 PSU. The experimental design is illustrated in Fig. 1A. Twenty cores with samples from Z. noltii vegetation were placed in a fiberglass pool and submerged in 4001 of seawater with continuous renewal at a dilution rate of $0.2 \mathrm{~h}^{-1}$. The water was vigorously bubbled with air to maintain turbulent conditions and the dissolved oxygen concentration in equilibrium with the atmosphere. The whole system was located within the greenhouse and thus preincubated overnight. This set-up corresponds to a $70 \mathrm{~cm}$ of water column above a $Z$. noltii vegetated sediment. At the start of the experiment (6:00 AM at sunrise) the system was run as a batch by stopping flow-trough of and renewal of fresh seawater. Immediately, three 5-1 portions of overlying seawater were withdrawn and incubated in 51 Erlenmeyer flasks representing the nonutrients amended treatment. Subsequently, an inorganic nutrient amendment was made to the water column of the mesocosm resulting in a final concentration of $45 \mu \mathrm{M} \mathrm{NO}_{3}{ }^{-}$and $5 \mu \mathrm{M}$ $\mathrm{PO}_{4}{ }^{3-}$. Fifteen minutes later, allowing for complete mixing, three 5-1 portions were withdrawn and incubated in 51 Erlenmeyer flasks representing the treatment Nutrients-amended +15 min. in contact with Z. noltii. Finally after $24 \mathrm{~h}$ of incubation in the mesocosm, three portions were withdrawn and incubated in 51 Erlenmeyer flasks representing the treatment Nutrientsamended $+24 \mathrm{~h}$. in contact with Z. noltii.

The microcosms were aerated with sterile air to maintain turbulent conditions and the dissolved oxygen concentration in equilibrium with the atmosphere. The Erlenmeyers were placed in a fiber glass pool with running seawater in order to keep the water temperature close to in situ conditions $\left(21-23^{\circ} \mathrm{C}\right)$. The incubations lasted for 5 days, time $\mathrm{T}=0$ is defined for each treatment as the time moment of withdrawal from the fiberglass pool and introduction into the microcosm Erlenmeyer flasks. The microcosms were sampled every $24 \mathrm{~h}$ for flow- 
cytometric analyses and determinations of nitrate and phosphate. Large volume samples ( 11 l $)$ were withdrawn only at day 3 and at the end (day 5) for detailed HPLC pigment analyses. All incubations were performed in the mesocosm facilities of the Laboratoire Océanographique d'Arcachon under semi-natural light conditions (> $60 \%$ of light transmission).

\section{Experiment 2}

Experiment 2 was performed early July 1998. The salinity of the water was 35 PSU. The experimental design is illustrated in Fig. 1B. Seven liter water samples were incubated in the greenhouse during $24 \mathrm{~h}$ in plastic containers that were placed in a fiberglass pool with water to allow temperature control of the systems at $21 \pm 2{ }^{\circ} \mathrm{C}$. Experiments were set up according a factorial design to test the pelagic-benthic interactions and the effects of nutrient enrichment. Treatments for testing the first factor comprised: 1: a Control, i.e. 71 water incubated alone

(labels: A, D), 2: 71 water together with one core of $Z$. noltii vegetation placed at the bottom of the container the whole system representing a $24.6 \mathrm{~cm}$ high water column above a Z. noltii covered tidal flat (labels: B, E), 3: 7 litre water amended with Z. noltii leaves harvested from one single core (labels: C, F). Two series of replicate microcosms (3 replicates per treatment) were incubated in parallel, one series without nutrient additions (Control for nutrient addition, labels: A, B, C) and one series was amended at $\mathrm{T}=0$ with $40 \mu \mathrm{M} \mathrm{NaNO} 3$ and $2.5 \mu \mathrm{M} \mathrm{NaH}_{2} \mathrm{PO}_{4}$ (labels: D, E, F). The water column in all containers was aerated by bubbling with air to maintain turbulent conditions and the dissolved oxygen concentration in equilibrium with the atmosphere. The microcosms were sampled at $\mathrm{T}=0$ and at $\mathrm{T}=24 \mathrm{~h}$ for cell densities by flowcytometry, inorganic nutrient concentrations and HPLC pigment analyses. All incubations were performed in the mesocosm facilities of the Laboratoire Océanographique d'Arcachon under semi-natural light conditions (> $60 \%$ of light transmission). 
Analyses

Inorganic nutrients. Samples for inorganic nutrients were filtered through GF/F glassfiber filters and directly frozen. Completely thawn samples were analyses for nitrate (as nitrite) and phosphate by standard colorimetric methods according Aminot \& Chaussepied (1983). Nitrate was reduced to nitrite by flow over a custom-made Cd column using a peristaltic pump to achieve a constant flow rate.

Phytoplankton counts were performed with a FACSCalibur flow cytometer (Becton Dickinson, San Jose, Ca) equipped with an air-cooled argon laser (488 nm, $15 \mathrm{~mW})$. Cells excited at $488 \mathrm{~nm}$, were detected and enumerated according to their right angle light scattering properties (RALS) and their orange $(585 / 42 \mathrm{~nm})$ and red fluorescence $(>650 \mathrm{~nm})$ emissions related to phycoerythrin and chlorophyll pigments, respectively. Fluorescent beads $(0.94-\mu \mathrm{m})$ (Polysciences Inc., Warrington, PA) were systematically added to each sample. The ratio of mean fluorescence or RALS of a cellular population to that of $0.94-\mu \mathrm{m}$ beads was used to normalize cell fluorescence emission and scatter values among samples. The precise volume analyzed and subsequent estimations of cell concentrations were calculated by measuring the remaining volume and subtracting it from the initial sub-sample volume (1-ml). Since part of the measured volume was used for flushing the sample line, the outer sleeve of the sample injection port of the flow cytometer was removed. Different phytoplanktonic groups were discriminated according to their fluorescence and scatter characteristics as described previously (Troussellier et al. 1997), thus distinguishing phycoerythrin-containing Synechococcus-like cells (SYN), phototrophic picoeukaryotes $(<3 \mu \mathrm{m}$, PEUK), nanophytoplanktonic cells $(>3 \mu \mathrm{m}$ and $<20 \mu \mathrm{m}, \mathrm{NAN})$ and larger phytoplanktonic cells (> $20 \mu \mathrm{m}, \mathrm{LARGP})$. 
HPLC-pigment analyses. Samples (1 L) were filtered over GF/F glass fiber filters, deep frozen and stored at $-80{ }^{\circ} \mathrm{C}$ until analyses. The filters were extracted twice in $100 \%$ acetone (due to the water content of the filters, the first extraction corresponded to 90-95\% acetone, and the second extraction $100 \%$ acetone). The two subsequent extracts were pooled and methylated and subjected to high performance liquid chromatography analyses according the protocol described by Buffan-Dubau et al. (2001).

Statistical analyses.

The pigment data in experiment 1 were analysed with a repeated measurement analyses of variance (rm-ANOVA) with the samplings in the different treatment replicates repeated at day 3 and day 5. Data expressed in $n g 1^{-1}$ were converted using the $\log (X+1)$ conversion to achieve homoscedasticity of data. Cell counts and pigment data of experiment 2 were analyzed with a factorial Two-way Anova (model 1) and post-hoc comparisons were tested using a Bonferroni correction for multiple comparisons. Calculations were performed with SysStat.

\section{Results}

\section{$\underline{\text { Experiment } 1}$}

Replicate incubations 5-1 portions were monitored for nutrient concentrations and phytoplankton growth during the five following days after exposure to the 3 different treatments. The time courses of the averaged concentrations of $\mathrm{NO}_{3}{ }^{-}$and $\mathrm{PO}_{4}{ }^{3-}$ are shown in Fig. 2. Selected pigment biomarkers concentrations are depicted for $\mathrm{T}=0$, day 3 and day 5 in Fig. 3 and the corresponding rmANOVA tests are listed in Table 1. Flow cytometric cell counts of the different phototrophic populations are depicted in Fig. 4. 
Fig. 2 shows that nutrient consumption by Z. noltii during $24 \mathrm{~h}$ resulted only in a minor reduction of the nutrient enrichment (compare values just after separation from the Z. noltii vegetation, i.e. at $\mathrm{t}=0, \mathrm{NO}_{3}{ }^{-}$concentrations were $36 \mu \mathrm{M}$ and $44 \mu \mathrm{M}$ and $\mathrm{PO}_{4}{ }^{3-}$ concentrations were $2.75 \mu \mathrm{M}$ and $4.9 \mu \mathrm{M}$, in the nutrients-amended treatments exposed to $Z$. noltii vegetation for $24 \mathrm{~h}$ and $15 \mathrm{~min}$, respectively). In both nutrients-amended treatments, phytoplankton growth between day 2 and day 5 clearly coincided with $\mathrm{N}$ and $\mathrm{P}$ uptake.

The pigment pattern indicated that the phytoplankton population mainly comprised diatoms (fucoxanthin), haptophytes (19' hexanoyl-oxyfucoxanthin), cyanobacteria (zeaxanthin) and green algae (chlorophyll b). In all microcosms, the pigments increased from day 0 to day 3 . rmANOVA indicated that treatment had a significant impact for most biomarker pigments at days 3 and 5, and within the treatments the interaction between time and treatment was also significant for fucoxanthin, 19' hexanoyl-oxyfucoxanthin and chlorophyll $a$. This means that for these pigments, the temporal patterns were different among the treatments. In both nutrients-amended treatments, the maximum pigment concentrations were about one order of magnitude higher than in the no-nutrients amended treatments. This effect was most pronounced for fucoxanthin for which maximum values were observed at day 5, representing about a twenty five times increase with respect to the no-nutrients amended treatment. This suggests that diatoms were particularly stimulated by nutrient enrichment. However, comparing both nutrients-amended treatments, the values of fucoxanthin and chlorophyll a at day three showed a delay of diatom growth in the treatment where the nutrients-amended water mass had been in contact with Zostera noltii for $24 \mathrm{~h}$.

The time course of the cell numbers in the microcosms where the nutrients-amended water mass had been in contact with Zostera noltii for $24 \mathrm{~h}$ showed a 1 day lag period before all populations increased (Fig. 4). In contrast, lag periods were not observed in the other treatments, which showed exponential increase of all groups until at least day 2. Accordingly, 
in the no-nutrients amended microcosms all groups showed net positive specific growth rates of $0.86,0.88,1.36$ and 1.36 day $^{-1}$ for SYN, PEUK, NAN, and LARGP, respectively. The time course of the cell numbers in the microcosms where the nutrient enriched water mass had only been in contact with Zostera noltii for $15 \mathrm{~min}$. after nutrient enrichment are remarkably similar (net positive specific growth rates of $0.82,0.69,1.35$ and 1.44 day $^{-1}$ SYN, PEUK, NAN, and LARGP, respectively) to the no-nutrients amended microcosms, except that large phytoplankton peaked at day 3 showing more than 6000 cells $/ \mathrm{ml}$, which is an order of magnitude higher than in the no-nutrients amended microcosms. In the nutrients-amended water mass that had been in contact with Zostera noltii for $24 \mathrm{~h}$, after the lag period, we observed net positive specific growth rates between 1 and 3 days of 1.11, 1.41, 1.19 and 1.04 day $^{-1}$ for SYN, PEUK, NAN, and LARGP, respectively.

In all treatments after day 3, the cell densities of SYN, PEUK, and NAN decreased exponentially. In contrast, LARGP showed differences among treatments. In the nutrientenriched water that had been exposed to $Z$. noltii for $24 \mathrm{~h}$, LARGP continued to increase until the end of day 5 with a net specific rate of 0.78 day $^{-1}$, while cell densities stabilized in both other treatments after day 3. Nevertheless, the maximum cell number of LARGP was about one order of magnitude higher in both nutrients-amended treatments compared to the no-nutrients amended treatment.

\section{Experiment 2.}

Seven-liter portions of water samples from the Bassin d'Arcachon were subjected to six treatments using a factorial design and each treatment $(\mathrm{A}-\mathrm{F})$ incubated in triplicate for 24 hours (see methods). Pigment biomarker concentrations and cell abundances of the different groups after $24 \mathrm{~h}$ are shown in figures 5 and 6, respectively, where these have been compared with their 
values at $\mathrm{t}=0$ (i.e., water used for starting the incubations). The results of the corresponding two-way ANOVA analyses are represented in Table 2.

No significant increase was observed for Fucoxanthin was not significantly influenced by nutrient enrichment $(\mathrm{p}>0.05)$, while the factor $Z$. noltii was significant $(\mathrm{p}=0.006)$, but the results are difficult to interpret because of extremely high variance caused by an outlier in the treatment + nutrients + above-ground parts of Z. noltii. 19'hexanoyl-oxy-fucoxanthin was influenced by nutrient enrichment $(\mathrm{p}=0.017)$, although surprisingly on average the values were $53 \%$ lower in the nutrients-amended control. Z. noltii vegetation, had a strong impact on this biomarker $(\mathrm{p}=0.006)$ : the values were reduced sixfold in the presence of $Z$. noltii vegetation compared to the water alone control. This effect was not observed when only above ground parts of Z. noltii were added. Zeaxanthin, was significantly influenced by nutrient amendment and showed on average a twofold increase with respect to no-nutrients amended treatments $(\mathrm{p}=0.039)$. The effect of $Z$. noltii was much stronger $(\mathrm{p}<0.001)$, i.e., compared to the water alone, on average this biomarker decreased by $93 \%$ and by $49 \%$ in the presence of Z. noltii vegetation and in presence of above-ground Z. noltii parts, respectively.

SYN were not significantly influenced by nutrient-enrichment in the short-term $24 \mathrm{~h}$ period, but incubation in presence of a $Z$. noltii vegetation significantly reduced SYN both with respect to water alone $(\mathrm{p}<0.001)$ and with respect to a corresponding amount of $Z$. noltii leaves $(\mathrm{p}=0.005)$. For PEUK a minor effect of nutrient enrichment $(16 \%$ average increase with respect to control, $\mathrm{p}=0.003$ ) was observed. However, the effect of adding $Z$. noltii leaves and Z. noltii vegetation was far more important for this group $(\mathrm{p}<0.001)$. With respect to $\mathrm{t}=0$, PEUK increased about three-fold when the water was incubated alone $(\mathrm{p}<0.001)$, decreased when the water was incubated in the presence of $Z$. noltii vegetation $(\mathrm{p}<0.001)$, and decreased slightly when water was incubated together with $Z$. noltii leaves $(\mathrm{p}=0.02656)$. 
NAN were most strongly influenced by nutrient amendment and showed on average a twofold increase with respect to no-nutrients amended treatments $(\mathrm{p}=0.003)$. However, again a systematic reduction of NAN with respect to $\mathrm{t}=0$ was also observed in the presence of $Z$. noltii vegetation ( $\mathrm{p}<0.001$ for both groups), but in contrast to PEUK the addition of $Z$. noltii leaves alone had no significant $(\mathrm{p}>0.05)$ effect with respect to water alone. Large phytoplancton (LARGP) was not significantly influenced by treatments $(\mathrm{p}>0.05$ for both factors). This group increased strongly with respect to $\mathrm{t}=0$.

\section{Nutrient uptake kinetics in experiments 1 and 2}

The nutrient addition treatments allowed us to calculate the uptake rates of inorganic nutrients following a pulse that are listed in Table 3. Both for nitrate and phosphate there was no significant difference between the rates in the presence of $Z$. noltii vegetation and its corresponding amount of $Z$. noltii leaves only. This means that in the Z. noltii vegetation, the leaves are responsible for the bulk of the inorganic nutrient uptake from the water column and that sediment-water column exchange plays a minor role. In contrast, when water was incubated alone, the nutrient uptake rate was 16 times lower for nitrate and 5 times lower for phosphate. Thus, planktonic microorganisms (D:E ratio compared to D, see Table 3) were responsible for $6 \%$ and $20 \%$ of the total uptake of $\mathrm{N}$ and $\mathrm{P}$, respectively in the $24.6 \mathrm{~cm}$ water column above a Z. noltii vegetation.

\section{Discussion}


In Experiment 1 we observed that phytoplankton development in nutrient-enriched Bassin d'Arcachon water was delayed when it remained in contact with Z. noltii vegetation for 24 hours. This experiment simulated what may happen in meso-tidal coastal lagoons where water masses enriched with nutrients from continental inputs, are only temporarily in contact with the intertidal Z. noltii vegetation according to tidal and hydrodynamic regimes. The morphology of the lagoon, the pattern of water flow and the local residence time in the lagoon will determine whether a given water mass will be in contact with intertidal vegetation during many successive high tide events or whether this mass becomes quickly separated from this interaction by flow to a part of the lagoon that is devoid of $Z$. noltii vegetation. Flushing and mixing further complicate the impact on phototrophic plankton in the coastal lagoon.

In Experiment 1, the densities of SYN, PEUK and NAN increased exponentially during the first three days of incubation in the treatment where the water mass was separated from the Z. noltii vegetation only 15 min after the nutrient addition and in the no-nutrients amended treatment. For the treatment nutrients-amended and $24 \mathrm{~h}$ in contact with $Z$. noltii vegetation, we observed that phytoplankton development in nutrient-enriched Bassin d'Arcachon water showed a lag time (1-2 days) before an exponential increase occurred between days 2 and 3, after separation from the vegetation. Surprisingly, the specific net growth rates did not follow an allometric relationship since only minor differences were observed between the different size classes, ranging from 0.69 to 1.44 day $^{-1}$, and, unexpectedly, the higher net specific growth rates were observed for the larger size class. After day 3, the population densities of SYN, PEUK and NAN decreased indicating that predation by micro-zooplancton exceeded growth rates. Conspicuously, the maximum cell numbers of SYN, PEUK and NAN did not show a significant impact of nutrient enrichment, which indicated that these groups were controlled by a top-down mechanism. Only LARGP benefited persistently from nutrient enrichment in the five-days experiments. This was not related to an increase of the initial net growth rates at the 
start of the incubation, but rather to the fact that exponential net growth of LARGP continued for three to four days in the nutrient-enriched mesocosms, while it leveled off after one day in the control. Thus, LARGP achieved higher maximum cell numbers in the nutrient-enriched mesocosms compared to the control. Moreover, after achieving a maximum, LARGP cell numbers remained stable showing that in these incubations they were hardly affected by grazing.

Because, in experiment 1 , the delay of phytoplankton growth could not be explained by competition for nutrients with Z. noltii (see Fig. 2), we envisioned that it might be explained by release of growth inhibitory compounds by Z. noltii. Recently, three phenolic compounds, i.e. rosmarinic, caffeic and zosteric acids, have been identified and quantified in tissues of Z. noltii sampled from different regions in Europe including the Bassin d'Arcachon (Grignon-Dubois et al., 2011). Other seagrasses including Zostera marina have been shown to produce secondary metabolites with allopathic growth inhibiting properties (Harrison and Chan, 1980; Todd et al., 1993; Jennsen et al., 1998).

Experiment 2 was designed to test the above-mentioned hypothesis and, in addition, also allowed us to separate the effects of the above-ground $Z$. noltii biomass from that of the entire vegetation including the sediment. This experiment 2 showed a surprisingly clear negative effect of the presence of $Z$. noltii vegetation on phytoplankton cell numbers. Nevertheless, the effect was most pronounced for NAN, SYN and PEUK only when complete vegetation including sediment was present. For NAN and PEUK, the treatment in presence of above-ground parts of $Z$. noltii was not significantly different from the corresponding water alone treatments, while only a minor but significant effect of above-ground biomass was observed for PEUK. For LARGP, none of the differences were significant. These results do neither support nor reject our first hypothesis that the negative effects on phytoplankton development can be attributed to secondary metabolites released from above-ground Z. noltii 
tissues. But, experiment 2 indicates a controlling role of the sediments that apparently overrules the impact of the above-ground Z. noltii biomass.

The spectacular decrease of PEUK, NAN and SYN and of the pigment biomarkers zeaxanthin and 19 'hexanoyl-oxyxanthin in a $24.6 \mathrm{~cm}$ high water column incubated above a $Z$. noltii vegetated sediment when compared to the same volume of water incubated alone (control), indicates that sediment infauna or epifauna exerted a predation pressure on the phytoplankton community of the overlying water column. Other studies in coastal environments have shown that suspension feeding sediment macrofauna can predate on different size classes of phytoplankton including picophytoplankton (Jordana et al., 2001a). Hence, an experimental study showed that the polychaete Ditrupa arietina retained diatoms, haptophytes and planktonic cyanobacteria with respective efficiencies of 84.7, 70.9 and 63.7 $\%$, respectively (Jordana et al., 2001b). Hence, benthic polychaetes may be responsible for the apparent reduction of phytoplankton groups. The macrofaunal assemblages at station A have been studied by Bachelet et al. (2000). It was observed that this assemblage showed little seasonal variations and was stable in time with a high biodiversity. The assemblage was numerically dominated by subsurface deposit feeding oligochaeta. Nevertheless, suspensionfeeding polychaeta occurred at high densities that exceeded 5000 ind. $\mathrm{m}^{-2}$ and 1000 ind. $\mathrm{m}^{-2}$ for Manayunkia aestuarina (Bourne) and Streblospio shrubsolii (Buchanan), respectively. In addition, suspension-feeding crustacean like Corophium spp. were common. Phytoplankton control due to benthic grazing in coastal lagoons and estuaries has been documented for mussel beds, oyster reefs (Dame et al., 1980; Dame et al., 1984; Jørgensen, 1990), and coral reefs (Genin et al., 2002), but, the role of benthic fauna living interspersed with seagrasses has received less attention so far. In contrast, it has been documented that suspension-feeding bivalves Modiolus americanus are able to control epiphytic communities occurring on the leaves of the seagrass Thalassia testidinum and a mutualistic interaction between these bivalves 
and seagrasses has been invoked (Petersen and Heck, 2001). Our study shows that it will be important to study in detail the potential impact of fauna associated with Z. noltii prairies on the phytoplankton communities in coastal lagoons.

Another source for interactions between the benthic vegetation and phytoplankton are the epiphytic communities growing on the Zostera noltii leaves and stems, particularly the leaves of Z. noltii may contain epifauna that selectively grazes on pico-eukaryotes. The epiphytes of $Z$. noltii are mainly composed of diatoms, while the faunistic part remains poorly described. By visual observations, we noticed that diatoms detached more easily from cut leaves than from intact plants, and the phytoplankton communities may therefore particularly be enriched in epiphytic species in the treatment with leaves amended. This seems to be reflected in higher fucoxanthin values with high standard deviations among replicates for this treatment, but was not reflected in higher cell numbers. Perhaps this can be explained by the fact that the benthic species are large cells and many contain fucoxanthin. Transfer of benthic diatoms to the pelagic compartment is particularly important in the field after storm events as has been inferred from phytoplankton monitoring studies in the Bassin d'Arcachon (MassonNeaud, 1998) and has also been suggested for Mediterranean lagoons (Gailhard et al., 2002).

In experiment 2, we detected significant positive effects of nutrient enrichment compared to control on cell densities for PEUK (on average $16 \%$ increase) and for NAN (on average a doubling) within $24 \mathrm{~h}$, while according the factorial design we were unable to detect effects of nutrient enrichments for SYN and LARGP. Because such effects might have been masked by the other factors and the short term $(24 \mathrm{~h})$ of the experiment we made comparisons with Experiment 1. In Experiment 1, we observed strong effects of nutrient enrichment after 3 and 5 days of incubation and most of the persistent increase of phytoplankton biomass in this experiment was attributed to LARGP. Thus, after 3 to 5 days of incubation, the chlorophyll $a$ and fucoxanthin concentrations increased by more than one order of magnitude in the nutrient- 
enriched microcosms with respect to the control. This clearly suggested that persistent large phytoplankton was dominated by diatoms and possibly with minor contributions of haptophytes and chlorophytes. Because we did not perform a size fractionation prior to pigment analyses, we can, however, not unambiguously relate the size class with its taxonomic composition, with the exception of SYN (Synechococcus sp.) that give a clear signal in the detector of the flow cytometer. The natural community as a whole was composed of diatoms, haptophytes, chlorophytes and cyanobacteria. Compared to the Etang de Thau, a French Mediterranean lagoon that as the Bassin d'Arcachon also has important oyster farming, in Arcachon the densities of picoeukaryotes are one to three orders of magnitude lower while Synechoccus densities are higher (cf. Vaquer et al., 1996).

In the nutrient enriched microcosms of Experiment 2, we measured that planktonic microorganisms contributed 6 and $20 \%$ to total $\mathrm{NO}_{3}{ }^{-}$and $\mathrm{PO}_{4}{ }^{3-}$ uptake rates in a Z. noltii system with a $24.6 \mathrm{~cm}$ overlying water column. The uptake rates were not significantly different when comparing the effect of $Z$. noltii vegetation with the corresponding amount of $Z$. noltii leaves. This means that in the $Z$. noltii vegetation, the leaves are responsible for the bulk of the inorganic nutrient uptake from the water column and that sediment-water column exchange plays a minor role. For Z. noltii leaves it has been determined that nitrate uptake occurs at comparable rates both during light and dark conditions according Michaelis-Menten kinetics with average $\mathrm{V}_{\max }=6 \mu \mathrm{mol} \mathrm{g}{ }^{-1} \mathrm{~h}^{-1}, \mathrm{Km}=7 \mu \mathrm{M}$ (De Wit et al., 2005); hence, at $40 \mu \mathrm{M}$ this corresponds to an uptake rate $\mathrm{V}=5.1 \mu \mathrm{mol} \mathrm{L} \mathrm{L}^{-1} \mathrm{~g}^{-1}$. The core has a surface of $0.0284 \mathrm{~m}^{2}$ and comprises therefore on average $2.13 \mathrm{~g}$ of $Z$. noltii leaves $\left(75 \mathrm{~g} \mathrm{~m}^{-2}\right)$, for 71 this corresponds to an uptake rate of $1.55 \mu \mathrm{mol} \mathrm{l}{ }^{-1} \mathrm{~h}^{-1}$. This value compares remarkably well with the value of 1.504 (i.e. $1.600-0.096) \mu \mathrm{mol} \mathrm{l}^{-1} \mathrm{~h}^{-1}$ calculated for uptake by Z. noltii according Table 3. Hence, the nutrient uptake rates can indeed be attributed mainly to uptake by the plant leaves which is described by Michaelis-Menten uptake kinetics. In the lagoon, the growing plants are 
thus an important sink for inorganic nutrients. Extrapolating these data to the scale of the lagoon, and on the basis of an average density of $150 \mathrm{~g} \mathrm{DW} / \mathrm{m}^{2}$ and an area of 7000 ha. (Auby \& Labourg, 1996; De Wit et al., 2001) in the Bassin d'Arcachon the potential uptake rates by Z. noltii per day were estimated to be equivalent to 7 and 2.5 metric tons per day for $\mathrm{N}$ and $\mathrm{P}$, respectively. For N, this compares to an average (1996-1999) daily N-loading of 4.4 metric tons per day (De Wit et al., 2005). Hence, the Z. noltii above-ground biomass has the potential to consume the entire N-loading into the lagoon and therefore, at the scale of the lagoon competition for $\mathrm{N}$ between phytoplankton and seagrass is probably important.

Conclusion. These experiments provide some first insights on the complex interactions between the major primary producers in the mesotidal coastal lagoon i.e. between phytoplankton and intertidal Z. noltii vegetation, which are depicted in Fig. 7. Phytoplankton has high potential intrinsic growth rates, but its standing biomass in the Bassin d'Arcachon is controlled by grazing, i.e. top-down control particularly for the SYN, PEUK and NAN groups. Collectively, Experiments 1 and 2 showed that phytoplankton densities in the Bassin d'Arcachon can be influenced by nutrient enrichment, but that the effects are complicated by the temporal interaction with the Z. noltii vegetation. Our data show that pelagic benthic coupling is particularly complicated in coastal tidal environments and that beside known classical biogeochemical phenomena (i.e. water-sediment nutrient fluxes) it encompasses a lot of unexpected ecological interactions. From experiment 1 we hypothesized a direct interference type of competition related to excretion or leaching of allelopathic substances from Z. noltii leaves. However, while experiment 2 did not allow rejecting this hypothesis, we discovered that the sediment with intact plants had a greater negative impact on the phytoplankton communities than addition of the leaves alone. This suggests that predation by benthic suspension feeders can play an important role. Therefore, novel experimental approaches 
should be developed that appropriately simulate the temporal variations of water volumes directly interacting with the benthic communities.

\section{Acknowledgements}

This study was supported by the European Union "Environment \& Climate" Programme (ROBUST project, contract N ENV4-CT96-218) and by the Ministry of Ecology and Sustainable Development (MEDD, Paris), contract LITEAU, LT 99064. Isabelle Auby and Danièle Maurer (both IFREMER, Arcachon) are kindly acknowledged for commenting on an earlier version of this manuscript.

\section{References}

Aminot, A. \& M. Chaussepied, 1983. Manuel des analyses chimiques en milieu marin. CNEXO, Brest

Auby I. \& P.-J. Labourg, 1996. Seasonal dynamics of Zostera noltii Hornem in the Bay of Arcachon (France). Journal of Sea Research 35: 269-277

Bachelet G., X. De Montaudouin, I. Auby \& P.-J. Labourg, 2000. Seasonal changes in macrophyte and macrozoobenthos assemblages in three coastal lagoons under varying degrees of eutrophication. ICES Journal of Marine Research 57: 1495-1506

Buffan-Dubau E., O. Pringault \& R. De Wit, 2001. Artificial cold-adapted mats cultured from Antarctic lake samples. 1. Formation and structure. Aquatic Microbial Ecology 26: 115125.

Burkholder J.M., D.A. Tomasko \& B.W.Touchette, 2007. Seagrass and eutrophication. Journal of Experimental Marine Biology Ecology 350: 46-72.

Caumette P., J. Castel \& R.A. Herbert, 1996. Coastal Lagoon Eutrophication and Anaerobic Processes. Hydrobiologia 329. Reprinted as Developments in Hydrobiology 117 (H.J. Dumont, Series editor). 253 pp. Kluwer, Dordrecht 
Dame R.F., R. Zingmark \& E. Haskin, 1984. Oyster reefs as processors of estuarine materials. Journal Experimental Marine Biology Ecology 83: 239-247

Dame R.F., R. Zingmark, H. Stevenson \& D. Nelson, 1980. Filter feeding coupling between the estuarine water column and benthic subsystems. In: Kennedy, V.S. (Ed.). Estuarine perspectives. Academic Press, New York, pp. 521-526

De Wit R., J. Leibreich, F. Vernier, F. Delmas, H. Beuffe, Ph. Maison, J.-C. Chossat, C. Laplace-Treyture, R. Laplana, V. Clavé, M. Torre, I. Auby, G. Trut, D. Maurer \& P. Capdeville, 2005. Relationship between land-use in the agro-forestry system of les Landes, nitrogen loading to and risk of macro-algal blooming in the Bassin d'Arcachon coastal lagoon (SW France). Estuarine Coastal Shelf Science 62: 453-465

De Wit R., L.J. Stal LJ, B.Aa. Lomstein, R.A. Herbert, H. Van Gemerden, P. Viaroli \& 16 others, 2001. "ROBUST: The ROle of BUffering capacities in STabilising coastal lagoon ecosystems. Continental Shelf Research 21: 2021-2041

Gailhard, I., P. Gros, J.P. Durbec, B. Beliaeff, C. Belin, E. Nézan \& P. Lassus, 2002. Variability patterns of microphytoplankton communities along the French coast. Marine Ecology Progress Series 242: 39-50

Green E.P. \& F.T. Short, 2003. World atlas of seagrasses. Prepared by the UNEP world conservation monitoring center. University of California Press, Berkeley, 298 pp.

Grignon-Dubois, M., B. Rezzonico \& T. Alcoverro, 2011. Regional scale patterns in seagrass defences: phenolic acid content in Zostera noltii. Estuarine Coastal Shelf Science doi:10.1016/j.ecss.2011.09.010|

Harrison P.G. \& A.T. Chan, 1980. Inhibition of the growth of micro-algae and bacteria by extracts of the eelgrass (Zostera marina) leaves. Marine Biology 61: 21-26

Jennsen P.R., K.M. Jenkins, D. Porter \& W. Fenical, 1998. Evidence that a new antibiotic flavone glycoside chemically defends the sea grass Thalassia testudinum against zoosporic fungi. Applied and Environmental Microbiology 64: 1490-1496

Jordana E., A. Grémare, F. Lantoine, C. Courties, F. Charles, J.-M. Amoureux \& G. Vétion, 2001a. Seasonal changes in the grazing of coastal picoplankton by the suspensionfeeding polychaete Ditrupa arietina (O.F. Müller). Journal of Sea Research 46: 245-259

Jordana E., F. Charles, A. Grémare, J.-M. Amoureux \& M.-J. Chrétiennot-Dinet, 2001b. Food sources, ingestion and absorption in the suspension-feeding polychaete, Ditrupa arietina (O.F. Müller). Journal of Experimental Marine Biology Ecology 266: 219-236

Jørgensen, C.B., 1990. Bivalve filter feeding: hydrodynamics, bioenergetics, physiology and ecology. Olsen \& Olsen, Fredensberg 
Laabir, M., M. Grignon-Dubois, P. Cecchi, B. Rezzonico, M. Rouquette \& E. Masseret, 2010. Allelopathic effects of Zostera spp on the growth and photosynthetic activity of the toxic dinoflagellate Alexandrium catenella. In UNEP - MAP - RAC/SPA, 2010. Proceedings of the Fourth Mediterranean Symposium on Marine Vegetation (YasmineHammamet, 2-4 December 2010), El Asmi S., H. Langar \& W. Belgacem edits., RAC/SPA publ., Tunis, pp187-188.

Masson-Neaud, N, 1998. Réseau de surveillance du phytoplancton (REPHY). Observations sur le Bassin d'Arcachon de 1991 à 1994 - Rapport interne IFREMER, DEL/9801/Arcachon, $53 \mathrm{pp}$.

McGlathery K.J., K. Sundbäck \& I.C. Anderson, 2007. Eutrophication in shallow coastal bays and lagoons: the role of plants in the coastal filter. Marine Ecology Progress Series 348: $1-18$.

Peterson B.J. \& K.L. Heck Jr, 2001. Positive interactions between suspension-feeding bivalves and seagrass - a facultative mutualism. Marine Ecology Progress Series 213: 143-155

Romero J., K.C. Lee, M. Pérez, M.A. Mateo \& T. Alcoverro, 2006. Nutrient dynamics in seagrass ecosystems. In Larkum A. W. D., R.J. Orth R.J. \& C.M. Duarte (eds) Seagrasses: Biology, Ecology and Conservation. Springer, Dordrecht, pp. 227-254

Schramm, W., 1999. Factors influencing seaweed responses to eutrophication: some results from EU-project EUMAC. Journal of Applied Phycology 11: 69-78.

Todd, J.T., R.C. Zimmerman, P. Crews \& R.S. Alberte, 1993. Isolation of p-sulfoxy cinnamic acid from Zostera marina L. (eelgrass) and the antifouling activity of phenolic sulfate esters. Phytochemistry 34: 401-404

Troussellier, M., C. Courties, P. Lebaron \& P. Servais. 1999. Flow cytometry discrimination of bacterial population in seawater based on Syto 13 staining of nucleic acids. FEMS Microbiology Ecology 29:319-330

Valiela, I., J. McClelland, J. Hauxwell, P.J. Behr PJ, D. Hersh \& K. Foreman, 1997. Macroalgal blooms in shallow estuaries: Control and ecophysiological and ecosystem consequences. Limnology and Oceanography 42: 1105-1118

Vaquer, A., M. Troussellier, C. Courties \& B. Bibent, 1996. Standing stock and dynamics of picoplancton in the Thau lagoon (northwest Mediterranean coast). Limnology and Oceanography 41: 1821-1828 
Viaroli, P., M. Bartoli, G. Giordani, M. Naldi, S. Orfanidis \& J.M. Zaldivar, 2008. Community shifts, alternative stable states, biogeochemical controls and feedbacks in eutrophic coastal lagoons: a brief overview. Aquatic Conservation: Freshwater and Marine Ecosystems, 18: S105-S117

Welsh, D.T., S. Bourguès, R.A. Herbert \& R. De Wit, 1996. Seasonal variation in nitrogen fixation (acetylene reduction) and sulphate reduction rates in the rhizosphere of Zostera noltii: nitrogen fixation by sulphate reducing bacteria. Marine Biology 125: 619-628 
Table 1: rmANOVA Results for pigment biomarkers in microcosms of Experiment 1 sampled at day 3 and day 5 after exposure to treatments (cf. Fig. 4).

\begin{tabular}{|c|c|c|c|}
\hline $\begin{array}{c}\text { Pigment } \\
\text { biomarker }\end{array}$ & Group & $\begin{array}{c}\text { Treatment effect } \\
\text { (time*treatment) }\end{array}$ \\
\hline Fucoxanthin & Diatoms & $* * *$ & $*$ \\
\hline $\begin{array}{c}19 \text { 'Hexanoyl- } \\
\text { oxyfucoxanthin }\end{array}$ & Haptophytes & $* * *$ & $\mathrm{~ns}$ \\
\hline Zeaxanthin & Cyanobacteria & $* * *$ & $\mathrm{~ns}$ \\
\hline Chlorophyll $b$ & Green algae & $*$ & $*$ \\
\hline Chlorophyll $a$ & All oxygenic & $* * *$ & \\
& phototrophs & & \\
\hline
\end{tabular}

ns: not significant, *: $\mathrm{p}<0.05, * *$ : $\mathrm{p}<0.01, * * *$ : $\mathrm{p}<0.001$ 
Table 2: ANOVA Results for Experiment 2, pigment (HPLC) data and cell count (FCM) data. Factor 1, i.e. nutrients comprises two groups: i) no-nutrients amended and ii) $40 \mu \mathrm{M}$ $\mathrm{NO}_{3}{ }^{-}$and $2.5 \mu \mathrm{M} \mathrm{PO}_{4}{ }^{3-}$ added. Factor 2, i.e. Zostera, comprises three groups: i) water alone, ii) water incubated together with $Z$. noltii vegetation and iii) water incubated with above-ground parts of Z. noltii. SYN = Synechococcus-like cells, PEUK = phototrophic picoeukaryotes $(<3 \mu \mathrm{m}), \mathrm{NAN}=$ nanophytoplankton $(>3 \mu \mathrm{m}$ and $<20$ $\mu \mathrm{m})$, and LARGP = larger phytoplanktonic cells $(>20 \mu \mathrm{m})$.

Factor Chlorophyll $a^{2)} \quad$ Zeaxanthin 19'Hexanoyl-oxy- Fucoxanthin fucoxanthin

$\begin{array}{lllll}1-\text { Nutrient } & \mathrm{ns} & * & * & \mathrm{~ns} \\ 2-\text { Zostera } & * & * * * & * * & * * \\ 1 \times 2 & \mathrm{~ns} & \mathrm{~ns} & \mathrm{~ns} & \mathrm{~ns}\end{array}$

$\begin{array}{lllll} & \text { SYN }^{1)} & \text { PEUK } & \text { NAN } & \text { LARGP } \\ 1-\text { Nutrient } & \mathrm{ns} & * * & * * & \mathrm{~ns} \\ 2-\text { Zostera } & * * * & * * * & * * * & \mathrm{~ns} \\ 1 \times 2 & \mathrm{~ns} & * & * & \mathrm{~ns}\end{array}$

1) For $S Y N$ after log transformation

2) For Chlorophyll a after square root transformation

ns: not significant, *: $\mathrm{p}<0.05, * *$ : $\mathrm{p}<0.01, * * *$ : $\mathrm{p}<0.001$ 
Table 3. Uptake rates of inorganic nutrients in the different nutrient enriched microcosms (addition of $40 \mu \mathrm{M} \mathrm{NO}_{3}{ }^{-}$and $2.5 \mu \mathrm{M} \mathrm{PO}_{4}{ }^{3-}$ at $\mathrm{t}=0$ ) of Experiment 1 compared with uptake rates observed in Experiment 2.

Microcosm $\quad \mathrm{N}\left(\mu \mathrm{mol} \mathrm{l}^{-1} \mathrm{~h}^{-1}\right) \quad \mathrm{P}\left(\mu \mathrm{mol} \mathrm{l}^{-1} \mathrm{~h}^{-1}\right)$

Experiment 1:

No-nutrients amended (from day 1 to day 3) $0.009 \quad 0.003$

+ Nutrients $15 \min$ (from day 2 to 5 ) $\quad 0.355 \quad 0.084$

+ Nutrients $24 \mathrm{~h}$ (from day 1 to 5$) \quad 0.221 \quad 0.015$

Experiment 2:
D: water alone
$0.096 \pm 0.074$
$0.014 \pm 0.005$
$\mathrm{E}:$ water $+Z$. noltti plants + sediment
$1.60 \pm 0.33$
$0.069 \pm 0.022$
$\mathrm{F}:$ water $+Z$. noltti leaves
$1.75 \pm 0.09$
$0.071 \pm 0.017$ 
Legends to Figures:

Fig. 1. Experimental protocols. Experiment 1 (top panel): Three different treatments were imposed in the mesocosm and subsequently treated samples were retrieved and consecutively incubated in microcosms for 5 days (see text of methods). Experiment 2 (bottom panel): Seven liter water samples were incubated in the greenhouse during $24 \mathrm{~h}$ in plastic containers that were placed in a fiberglass pool with water to allow temperature control of the systems at $21 \pm 2{ }^{\circ} \mathrm{C}$. Experiments were set up according a factorial design to test the pelagic-benthic interactions and the effects of nutrient enrichment (see text of methods).

Fig. 2 Results of Experiment 1 (see Methods). Time courses of nitrate and phosphate concentrations in the microcosms incubations after separation of the water mass from the interaction with the $Z$. noltii system following the different treatments described in the labels. Data points represent arithmetic mean values of the three replicates and their standard deviations are indicated by the error bars. Note difference of scale for left-hand graph.

Fig. 3 Results of Experiment 1 (see Methods). Water column concentrations of selected biomarker pigments (see labels) in the microcosms incubations at $\mathrm{T}=0, \mathrm{~T}=3$ days and $\mathrm{T}=5$ days, after separation of the water mass from the interaction with the $Z$. noltii system following the different treatments described in the labels. Bars represent arithmetic mean values of the three replicates and their standard deviations are indicated by the error bars. Note differences of scale for upper panel.

Fig. 4 Results of Experiment 1 (see Methods). Time courses of cell numbers in the microcosms incubations after separation of the water mass from the interaction with the Z. noltii system following the different treatments described in the labels. SYN = Synechococcus-like cells, PEUK = phototrophic picoeukaryotes $(<3 \mu \mathrm{m})$, NAN = nanophytoplankton ( $>3 \mu \mathrm{m}$ and $<20 \mu \mathrm{m}$ ), and LARGP = larger phytoplanktonic cells (> $20 \mu \mathrm{m}$ ). Data points represent arithmetic mean values of the three replicates and their standard deviations are indicated by the error bars. 
Fig. 5 Results of Experiment 2 (see Methods). Water column concentrations of selected biomarker pigments (see labels) for the different treatments after $24 \mathrm{~h}$ of incubation ( $\mathrm{T}=$ $24 \mathrm{~h}$ ) in the microcosms compared with their values observed at $\mathrm{T}=0$ in the water mass used as a start in the microcosms. Bars represent arithmetic mean values of the three replicates and their standard deviations are indicated by the error bars.

Fig. 6 Results of Experiment 2 (see Methods). Cell numbers of the different phytoplankton classes (see labels) for the different treatments after $24 \mathrm{~h}$ of incubation $(\mathrm{T}=24 \mathrm{~h})$ in the microcosms compared with the cell numbers observed at $\mathrm{T}=0$ in the water mass used as a start in the microcosms. SYN = Synechococcus-like cells, PEUK = phototrophic picoeukaryotes $(<3 \mu \mathrm{m}), \mathrm{NAN}=$ nanophytoplankton $(>3 \mu \mathrm{m}$ and $<20 \mu \mathrm{m})$, and LARGP $=$ larger phytoplanktonic cells $(>20 \mu \mathrm{m})$. Bars represent arithmetic mean values of the three replicates and their standard deviations are indicated by the error bars.

Fig. 7 Drawing of Zostera noltii showing below- and above ground parts of the plants (bottom panel) and a tentative conceptual scheme of the interactions between Z. noltii vegetation including its associated sediment communities and phytoplankton when the intertidal $Z$. noltii vegetation is immerged. The broken lines represent an indirect facilitative interaction. 


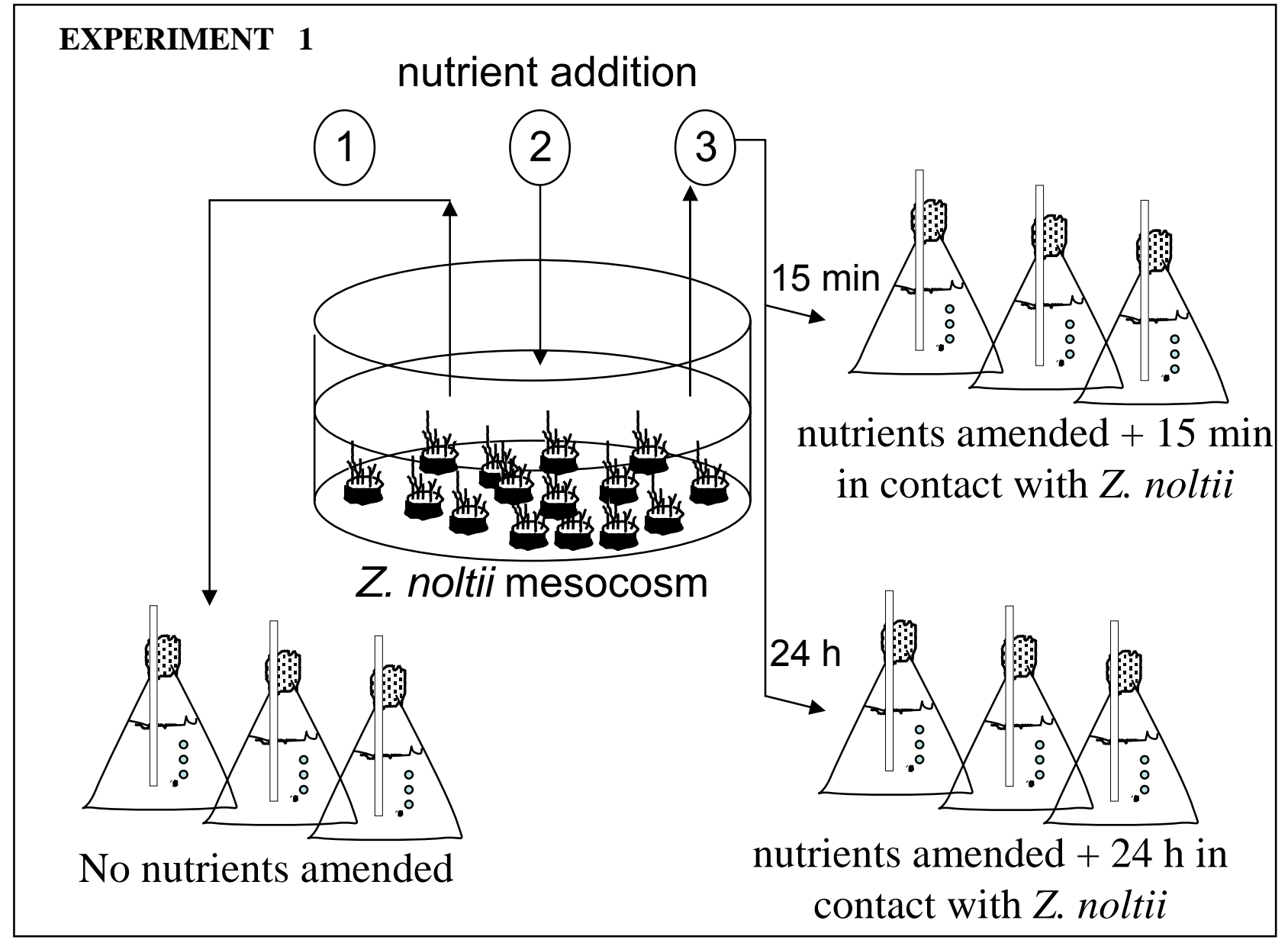

EXPERIMENT 2

water $+Z$. noltii vegetation (including sediment)

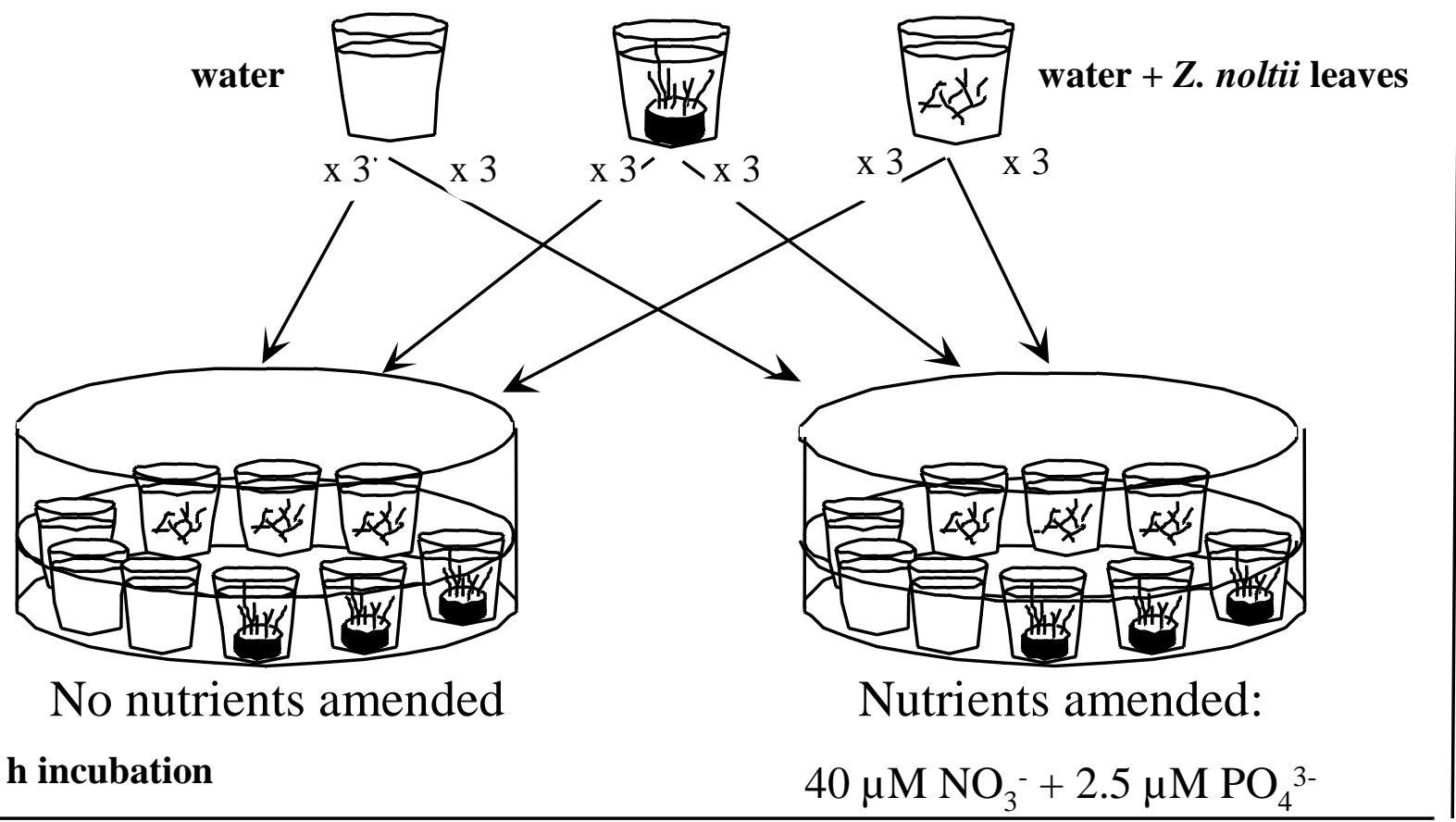




\section{No nutrients amended}

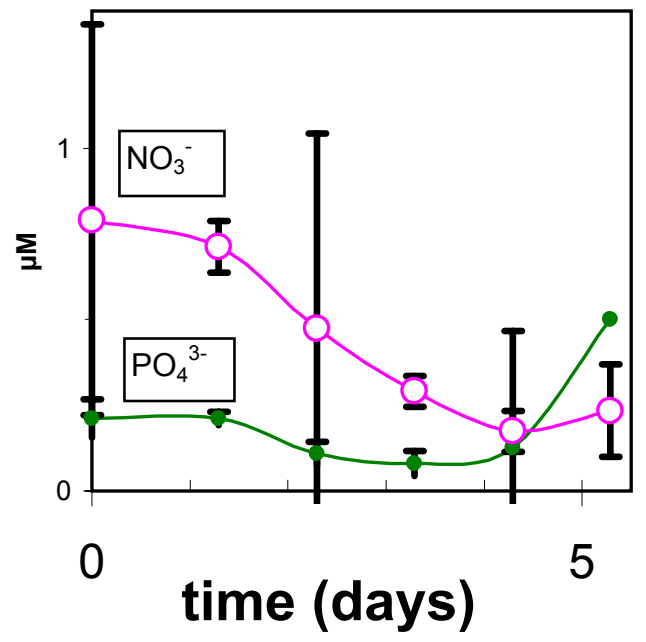

\section{Nutrients amended +}

$15 \mathrm{~min}$. in contact with $Z$. noltii

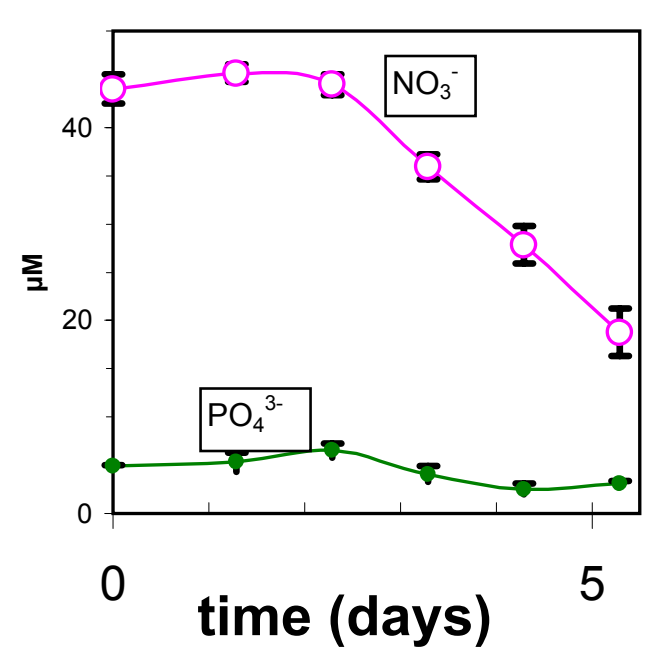

Nutrients amended +

$24 \mathrm{~h}$ in contact with $Z$. noltii

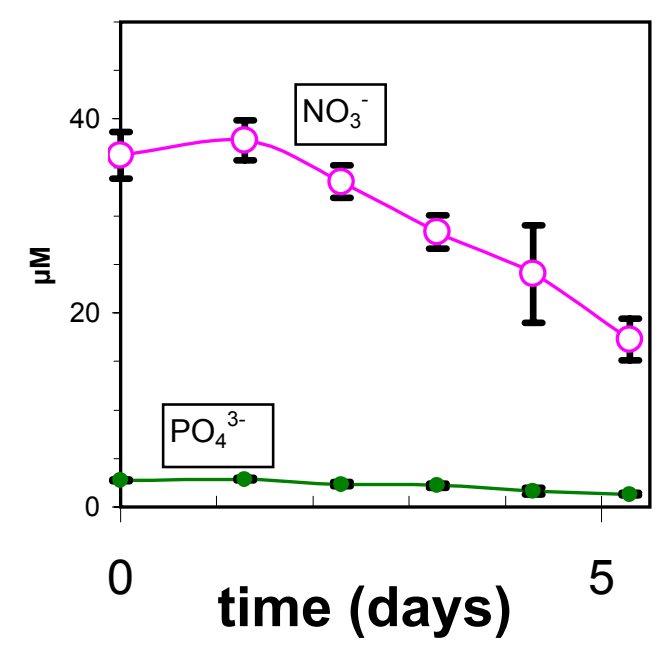




\begin{tabular}{ll}
\hline Gucoxanthin & $\quad$ 19'Hexanoyl-oxyfucoxanthin \\
$\square$ Zeaxanthin & $\square$ Chlorophyll b \\
$\square$ Chlorophyll a & \\
\hline
\end{tabular}
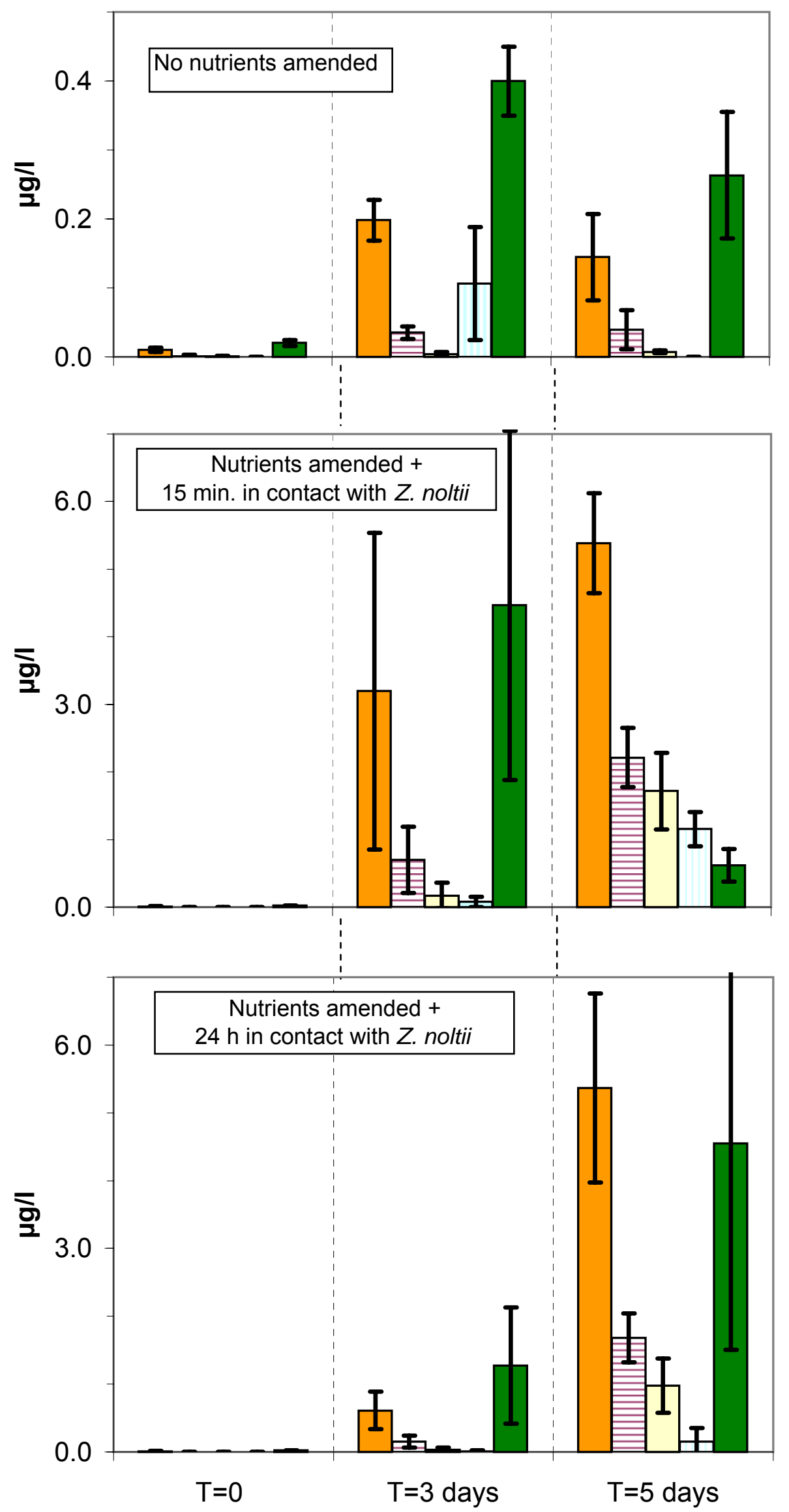

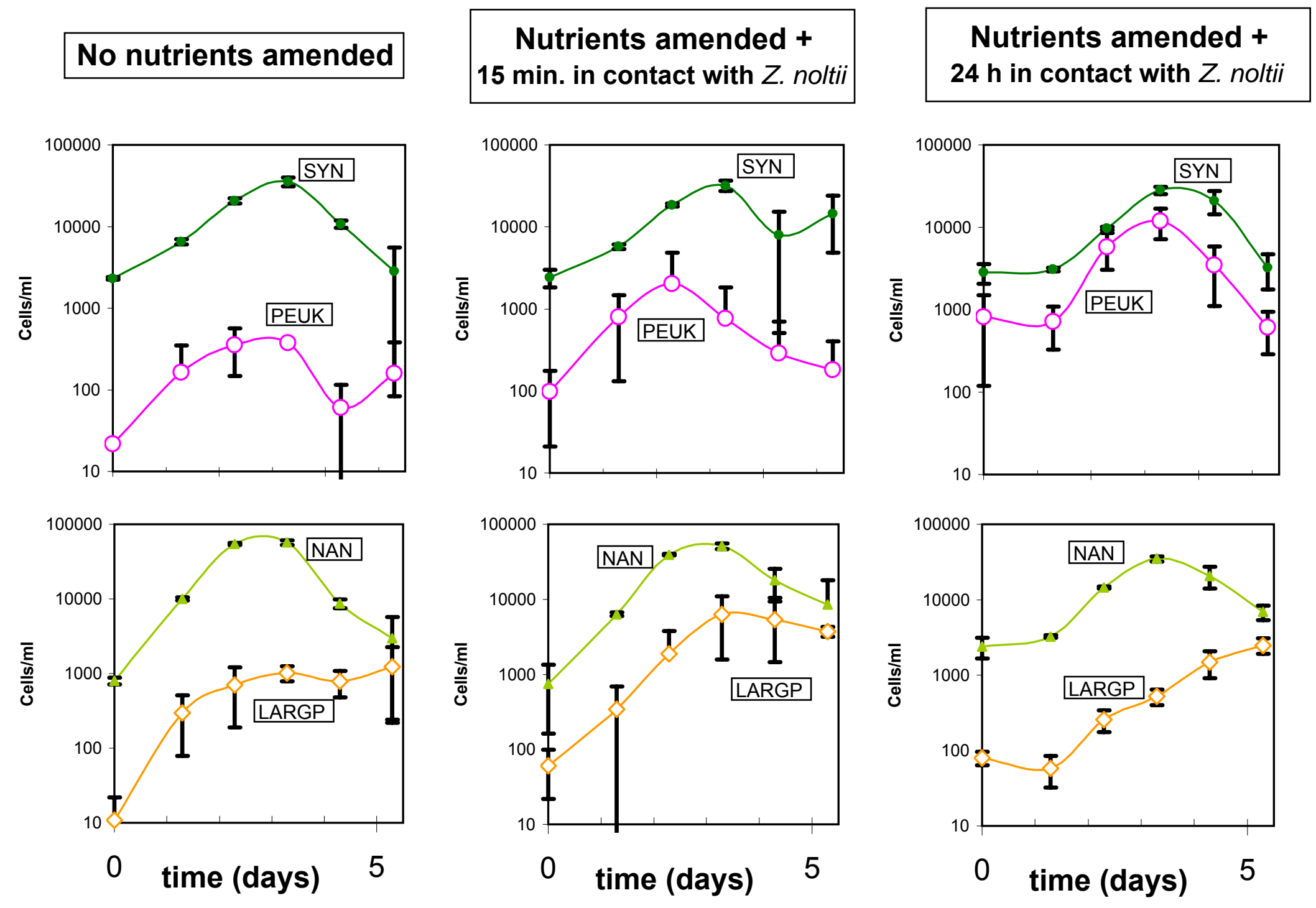


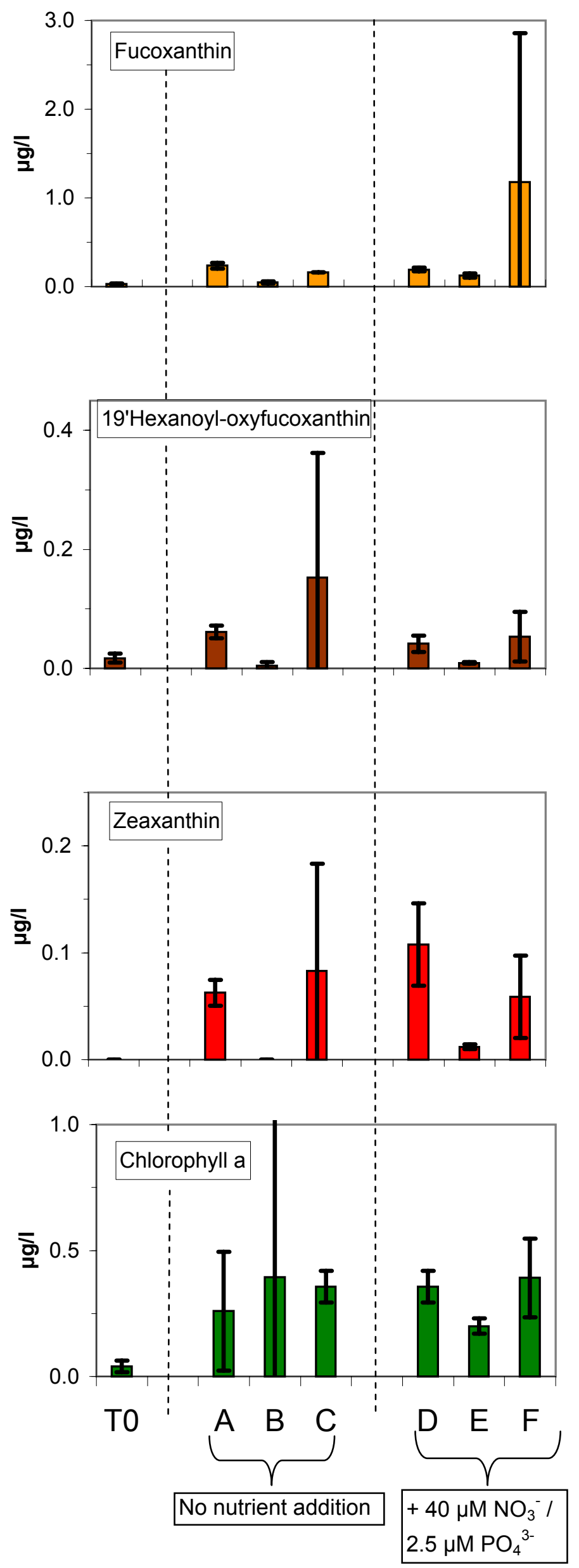



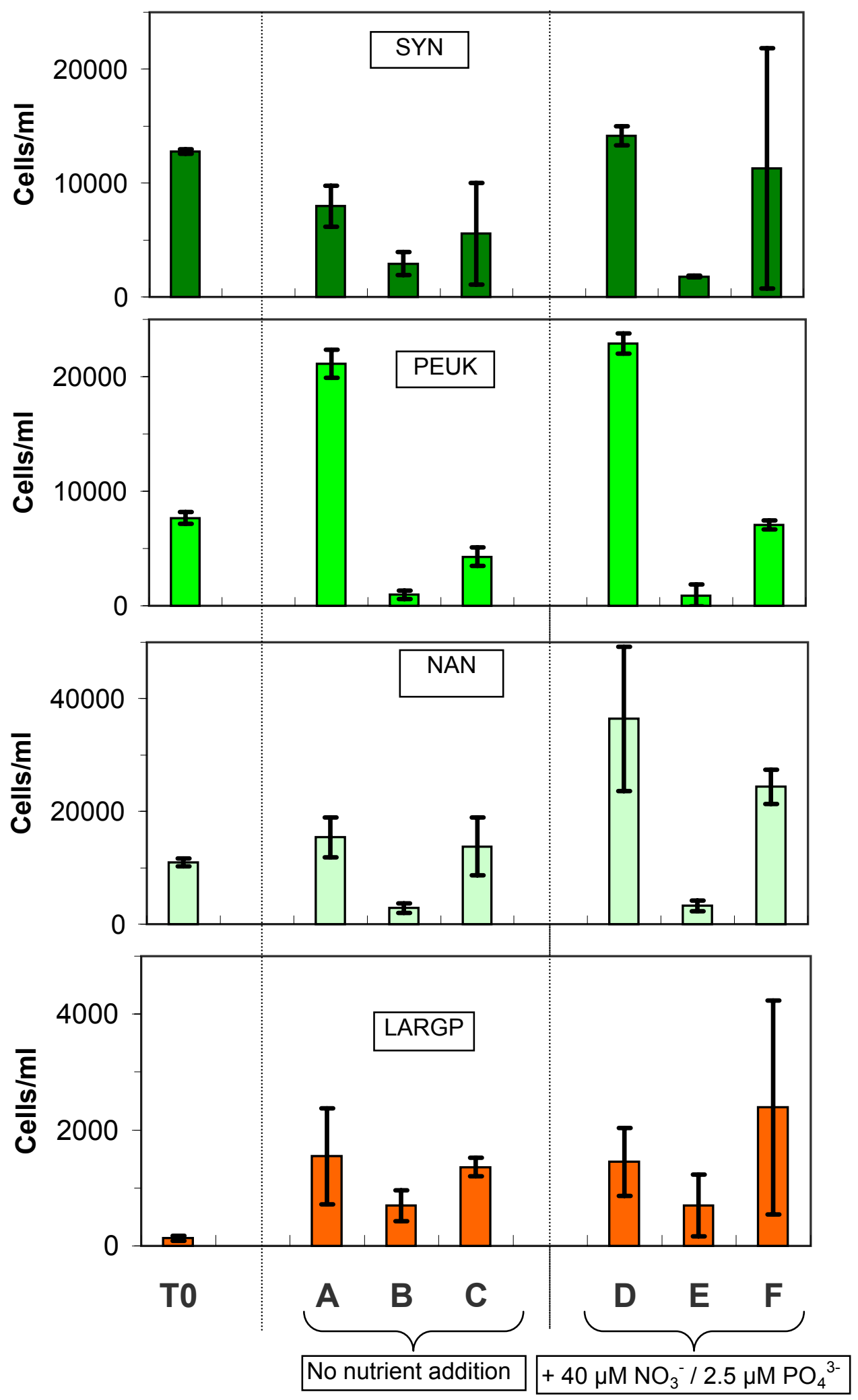


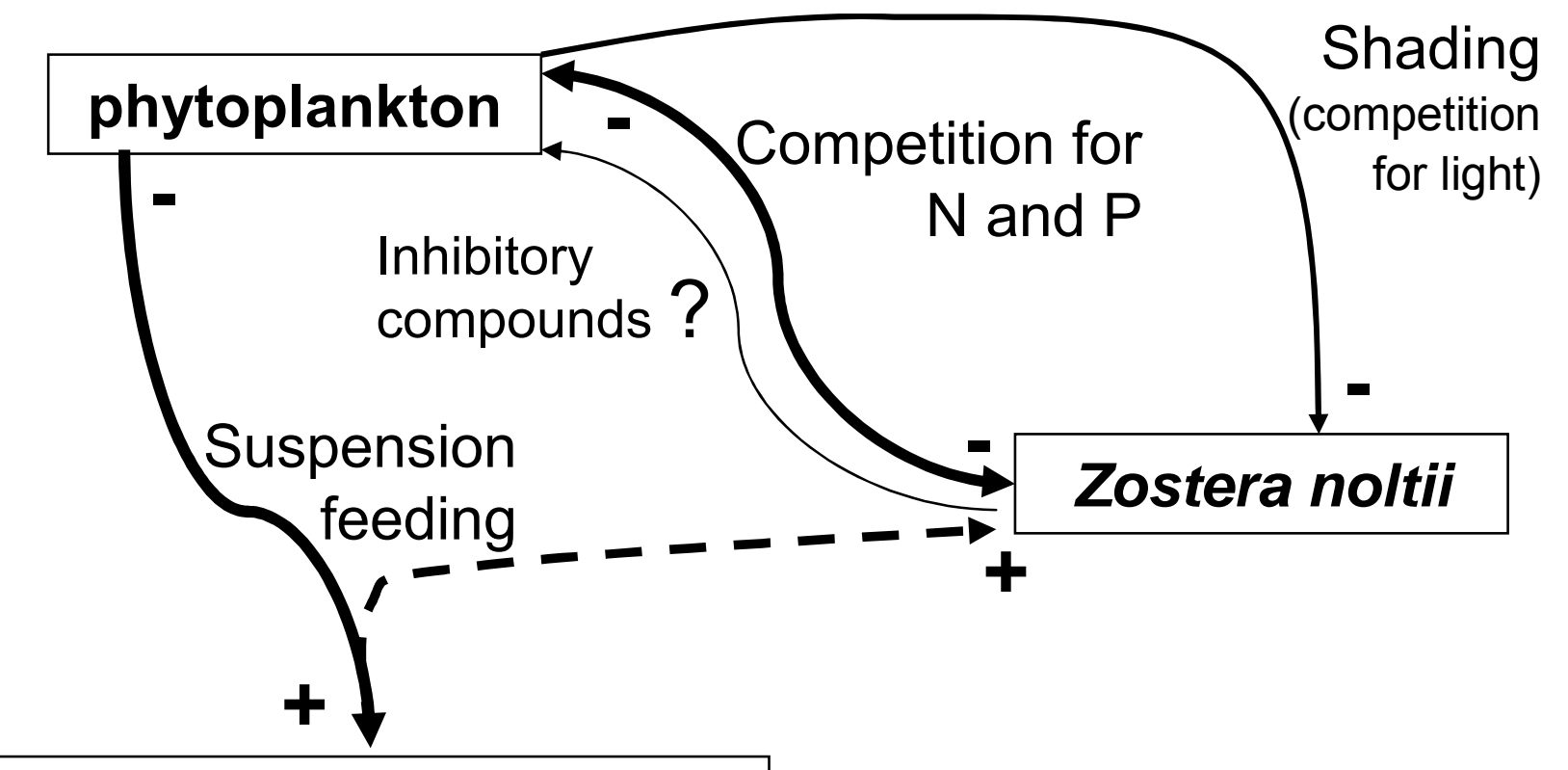

\section{benthic epi- and infauna}

Above-ground biomass

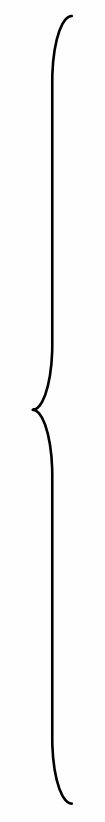

Below-ground biomass

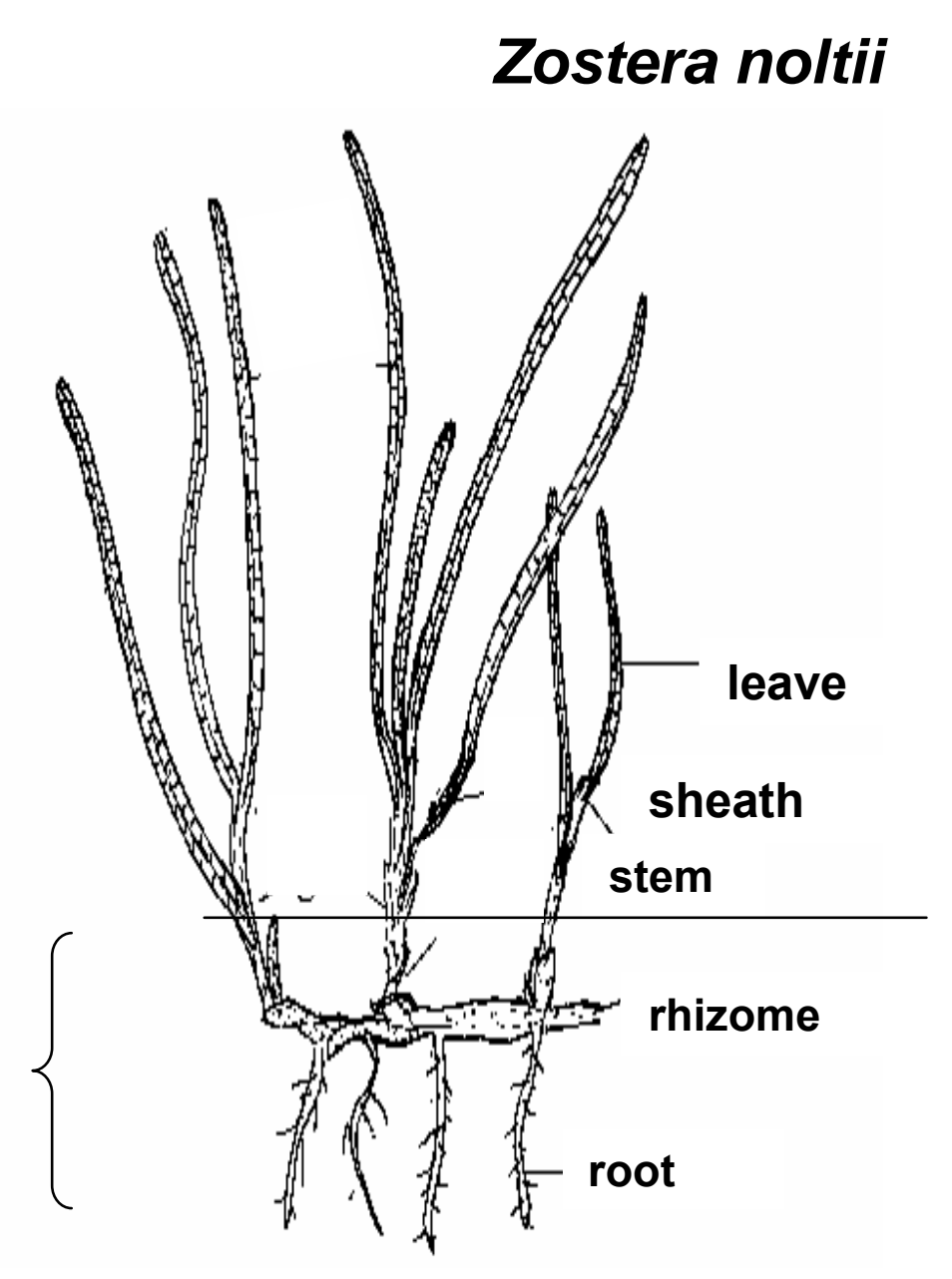

